\title{
TINJAUAN YURIDIS PELAKSANAAN PEMBATALAN PERKAWINAN DI PENGADILAN AGAMA
}

\author{
SUWARDI \\ Dosen Fakutas Hukum Universitas Ekasakti \\ suwardi531@gmail.com
}

\begin{abstract}
In the provisions of the law, marriage must be carried out in accordance with the terms and conditions of marriage. One of the conditions of the marriage is an agreement between the parties who wish to marry, including knowing the identity of each party. This means that a marriage is prohibited if it does not meet the requirements, while such a marriage which has already been carried out can be canceled. In the writing of this thesis, research was carried out on problems in the form of the process of implementing an application for a marriage cancellation case at the Religious Court and the legal consequences of cancellation of marriage on children and joint assets. In the research method used was normative juridical. The procedure for filing a cancellation request at the Religious Court begins with registration of the application and goes through several administrative processes which are then followed by a trial where at the first trial the panel of judges is obliged to reconcile the applicant with the respondent, furthermore, the cancellation of the marriage has a legal effect on the relationship between the applicant and the respondent which is no longer bound by ties. a legal and essential marriage, and there is no civil obligation for the applicant or the respondent.
\end{abstract}

Keywords: Cancellation, Marriage, Religious Court

Abstrak: Ketentuan dalam hukum, perkawinan harus dilaksanakan dengan memenuhi syarat-syarat dan rukun perkawinan. Salah satu syarat dari perkawinan itu adalah adanya kesepakatan antara para pihak yang hendak melangsungkan perkawinan, termasuk didalamnya dengan diketahuinya identitas diri masing-masing pihak. Ini berarti bahwa perkawinan itu dilarang bila tidak memenuhi syarat-syarat, sedangkan perkawinan semacam itu yang sudah (terlanjur) terlaksana, dapat di batalkan. Dalam penulisan skripsi ini dilakukan penelitian terhadap masalah berupa proses pelaksanaan permohonan perkara pembatalan perkawinan di Pengadilan Agama dan akibat hukum pembatalan perkawinan terhadap anak dan harta bersama. Dalam penelitian metode yang digunakan adalah yuridis normatif. Prosedur dalam mengajukan permohonan pembatalan di Pengadilan Agama diawali dengan pendaftaran permohonan dan melewati beberapa proses administrasi yang selanjutnya sidang dimana pada sidang pertama majelis hakim wajib mendamaikan antara pemohon dengan termohon, selanjutnyapembatalan perkawinan menimbulkan akibat hukum terhadap hubungan antara pemohon dan termohon sudah tidak terikat lagi dengan ikatan perkawinan yang sah dan hakiki,dan tidak adanya kewajiban perdata bagi pemohon maupun termohon.

Kata Kunci: Pembatalan, Perkawinan, Pengadilan Agama 


\section{A. Pendahuluan}

Manusia sebagai makhluk Tuhan yang mempunyai derajat yang paling tinggi dibandingkan makhluk yang lainnya. Dalam kehidupannya manusia mempunyai kebutuhan biologis yang merupakan tuntutan naluriah. Untuk memenuhi kebutuhan tersebut diadakan perkawinan sebagai jalan keluarnya. Dengan tujuan agar makhluk ciptaan Tuhan didunia berkembang biak. Tujuan dari diciptakan berpasangan itu adalah untuk melakukan perkawinan sebagai sarana untuk melangsungkan keturunan. Khusus untuk manusia, apabila telah mencapai usia tertentu dan telah memenuhi persyaratan untuk melakukan perkawinan dianjurkan untuk menikah.Karena perkawinan adalah sunatullah, jadi merupakan suatu ibadah bila melaksanakan sunatullah tersebut. Perkawinan diatur oleh hukum agama, maka seseorang yang akan melaksanakan perkawinan harus berpedoman pada aturan tentang perkawinan yang telah digariskan oleh hukum agamanya, sebagaimana diatur dalam Pasal 2 ayat (1) UU No. 1 Tahun 1974 yang menyebutkan bahwa "Perkawinan adalah sah, apabila dilakukan menurut hukum masing-masing agamanya dan kepercayaannya itu". "Yang dimaksud dengan hukum masing-masing agama dan kepercayaannya itu sepanjang tidak bertentangan atau tidak ditentukan lain dalam undang-undang ini" (Sudarsono, 2005).

Selain itu, perkawinan akan tercapai apabila perkawinan itu memenuhi beberapa syarat dan rukun. Adapun syarat-syarat untuk melakukan perkawinan sebagaimana tercantum dalam Undang-undang perkawinan adalah (Syahrani Riduan, 1978): 1) Adanya persetujuan kedua calon mempelai; 2) Adanya izin dari kedua orang tua/wali bagi calon mempelai yang belum berusia 21 tahun; 3) Usia calon mempelai pria sudah mencapai 19 tahun dan usia calon mempelai wanita sudah mencapai 16 tahun kecuali ada dispensasi dari pengadilan; 4) Antara calon mempelai pria dan calon mempelai wanita tidak dalam hubungan keluarga/darah yang tidak boleh kawin; 5) Calon mempelai wanita tidak dalam ikatan perkawinan dengan pihak lain dan calon mempelai pria juga tidak dalam ikatan perkawinan dengan pihak lain, kecuali telah dapat izin dari pengadilan untuk poligami; 6) Bagi suami istri yang telah bercerai, lalu kawin lagi dan kemudian bercerai lagi, agama dan kepercayaan mereka tidak melarang mereka untuk kawin kembali (untuk ketiga kalinya); dan 7) Tidak dalam waktu yang di tunggu bagi calon mempelai wanita.

Rukun perkawinan menurut Pasal 14 KHI adalah: 1) Adanya pihak yang melaksanakan akad nikah, yaitu mempelai pria dan wanita; 2) Wali nikah; 3) dua orang saksi; 4) Ijab dan Kabul. Pasal 22 Undang-undang Nomor 1 Tahun 1974, menyatakan bahwa perkawinan dapat dibatalkan, apabila para pihak tidak memenuhi syarat-syarat untuk melangsungkan perkawinan. Ini berarti bahwa perkawinan itu dilarang bila tidak memenuhi syarat-syarat,sedangkan perkawinan semacam itu yang sudah (terlanjur) terlaksana, dapat dibatalkan (Sosroatmodjo Arso, 1981). Kenyataannya dalam masyarakat masih ada orang-orang yang melaksanakan perkawinan padahal ada syarat-syarat yang tidak terpenuhi atau ada larangan-larangan 
yang telah dilanggar. Misalnya menikah secara diam-diam, tanpa sepengetahuan istri, tanpa didaftarkan dipencatatan nikah, dan ada juga yang menggunakan identitas palsu.

Jika ini terjadi, pengadilan dapat membatalkan perkawinan atas permohonan pihak-pihak yang berkepentingan. Adapun pihak-pihak yang berkepentingan mengajukan pembatalan perkawinan adalah para keluarga dalam garis lurus ke atas dari suami atau istri,pihak yang bersangkutan atau pejabat yang berwenang atau ditunjuk. Apabila pihak yang dirugikan tidak membatalkan perkawinan tersebut, maka perkawinan tersebut tetap berlangsung.

\section{B. Metodologi Penelitian}

Untuk melakukan penelitian ini dan untuk melengkapi bahan-bahan atau data yang konkrit, jawaban yang objektif dan ilmiah serta dapat dipertanggung jawabkan kebenarannya, maka tulisan mengenai pelaksanaan pembatalan perkawinan di Pengadilan Agama. Penelitian ini merupakan penelitian deskriptif analitis yang menggambarkan tentang peran deponering dalam perkara pidana di Indonesia. Pendekatan yang digunakan dalam penelitian ini adalah pendekatan yuridis normatif, digunakan untuk mengetahui tentang pelaksanaan pembatalan perkawinan di Pengadilan Agama.

\section{Hasil dan Pembahasan}

Perkawinan dapat dibatalkan, apabila para pihak tidak memenuhi syarat-syarat untuk melangsungkan perkawinan. Pasal 28 UU Perkawinan menetapkan bahwa batalnya perkawinan dimulai setelah keputusan pengadilan mempunyai kekuatan hukum tetap dan berlaku sejak saat berlangsungnya pembatalan perkawinan. "Pengertian pembatalan perkawinan menurut Riduan Syahrani adalah suatu perkawinan yang dilaksanakan oleh para pihak(suami atau istri) terbukti tidak memenuhi syarat-syarat untuk melangsungkan perkawinan". "Pengertian pembatalan perkawinan menurut Bakri A Rahman dan Ahmad Sukardja adalah suatu perkawinan yang sudah terjadi dapat dibatalkan,apabila pihak tidak memenuhi syarat-syarat untuk melangsungkanperkawinan dan pembatalan perkawinan tersebut hanya dapat diputuskan oleh pengadilan".

Pasal 23 Undang-Undang perkawinan, yang dapat mengajukan pembatalan perkawinan adalah (Ichsan Achmad, 1987): 1) Para keluarga dalam garis keturunan lurus ke atas dari suami atau istri; 2) Suami atau istri; 3) Pejabat yang berwenang hanya selama perkawinan belum diputuskan; dan 4) Setiap orang yang mempunyai kepentingan hukum secara langsung terhadap perkawinan tersebut, tetapi setelah perkawinan itu putus.

Pembatalan perkawinan dapat pula diajukan oleh wali nikah sesuai dengan ketentuan Pasal 26 UU Perkawinan dengan beberapa ancaman: 1) Perkawinan yang dilangsungkan di muka pegawai pencatat perkawinan yang tidak berwenang,wali nikah, yang tidak sah atau yang dilangsungkan tanpa dihadiri oleh 2orang saksi dapat dimintakan pembatalannya oleh para keluarga dalam garis keturunan lurus ke atas dari suami atau istri, jaksa dan suami atau istri; dan 2) Hak untuk membatalkan oleh suami atau istri berdasarkan alasan dalam ayat (1) pasal ini gugur apabila mereka telah hidup bersama sebagai suami istri dan dapat memperlihatkan akte perkawinan yang dibuat pegawai pencatat perkawinan yang tidak berwenang dan perkawinan harus diperbaharui supaya sah. 
Pasal 27 UU Perkawinan menyatakan: 1) Seorang suami atau istri dapat mengajukan permohonan pembatalan perkawinan apabila perkawinan dilangsungkan di bawah ancaman yang melanggar hukum; 2) Seorang suami atau istri dapat mengajukan permohonan pembatalan perkawinan apabila pada waktu berlangsungnya perkawinan terjadi salah sangka mengenai diri suami atau istri; dan 3) Apabila ancaman telah berhenti, atau yang bersalah sangka itu menyadari keadaannya dan dalam jangka waktu 6 (enam) bulan setelah itu masih tetap hidup sebagai suami istri dan tidak mempergunakan haknya untuk mengajukan permohonan pembatalan, maka haknya gugur. Dan dalam Pasal $74 \mathrm{KHI}$, permohonan pembatalan perkawinan dapat diajukan ke Pengadilan Agama yang mewilayahi tempat tinggal suami atau istri atau tempat perkawinan dilangsungkan.

Menurut Pasal $70 \mathrm{KHI}$, alasan seseorang mengajukan pembatalan perkawinan adalah: 1) Suami melakukan perkawinan, sedang ia tidak berhak melakukan akad nikah karena sudah mempunyai empat orang istri, sekalipun salah satu dari keempat istrinya itu dalam masa iddah talak raj'I; 2) Seseorang menikahi bekas istrinya yang telah dili'annya; 3) Seseorang menikahi bekas istrinya yang pernah dijatuhi tiga kali talak olehnya, kecuali bekas istrinya tersebut telah pernah menikah dengan pria lain yang kemudian bercerai lagi ba'da al dukhul dari pria tersebut dan telah habis masa iddahnya; 4) Perkawinan dilakukan antara dua orang yang mempunyai hubungan darah semenda dan sesusuan sampai derajat tertentu yang menghalangi perkawinan menurutpasal 8 Undang-undang No. 1 Tahun 1974, yaitu: Berhubungan darah adalah garis lurus ke bawah dan ke atas; Berhubungan darah dalam garis keturunan menyamping yaitu antara saudara, antar seeorang dengan saudara orang tua, dan antara seseorang dengan saudara neneknya; Berhubungan semenda, yaitu mertua, anak tiri, menantu, dan ibu atau ayah tiri;Berhubungan sesusuan, yaitu orang tua sesusuan, anak sesusuan, saudara sesusuan, dan bibi atau paman sesusuan: dan 5) Istri adalah saudara kandung atau sebagai bibi atau kemenakan dari istri atau istri-istrinya.

Selain itu, menurut Pasal 71 KHI sesorang dapat juga mengajukan pembatalan perkawinan apabila: a) Seorang suami melakukan poligami tanpa izin pengadilan agama; b) Perempuan yang dikawini ternyata kemudian diketahui masih menjadi istri pria lain yang mafqud; c) Perempuan yang dikawini ternyata masih dalam 'iddah dari suami lain; d) Perkawinan yang melanggar batas umur perkawinan sebagaimana ditetapkan dalam Pasal 7 Undang-undang Nomor 1 Tahun 1974; e) Perkawinan dilangsungkan tanpa wali atau dilaksanakan oleh wali yang tidak berhak; dan f) Perkawinan yang dilaksanakan dengan paksaan. Dalam Pasal 75 KHI, disebutkan bahwa akibat hukum terhadap pembatalan perkawinan tidak berlaku surut terhadap: 1) Perkawinan yang batal karena salah satu dari suami atau istri murtad; 2) Anak-anak yang dilahirkan dari perkawinan itu; dan 3) Pihak ketiga sepanjang mereka memperoleh hak-hak dengan beritikad baik, sebelum keputusan pembatalan perkawinan mempunyai kekuatan hukum tetap.

Pada Pasal 76 disebutkan bahwa "batalnya suatu perkawinan tidak memutuskan hubungan antara anak dengan orang tuanya". Bagi anak-anak yang lahir dari perkawinan yang dibatalkan,anak-anak itu dianggap anak-anak yang sah, jadi anakanak itu dapat mewaris dari ayahnya (ibunya) dan juga anak itu mempunyai hubungan kekeluargaan dengan keluarga ayahnya (ibunya) (Afandi Ali, 1984). Dalam Pasal 85 Kompilasi Hukum Islam dinyatakan bahwa "adanya harta bersama dalam perkawinan itu tidak menutup kemungkinan milik masing-masing suami atau istri". Oleh karena itu, harta bawaan suami, merupakan milik suami dan dikuasai sepenuhnya oleh suami serta harta bawaan istri, merupakan milik istri dan sepenuhnya menjadi milik istri E-ISSN: 2657-0300 $\quad$ Lembaga Penelitian dan Penerbitan Hasil Penelitian Ensiklopedia $\quad 81$ 
sepanjang para pihak tidak menentukan lain dalam perjanjian perkawinan. Harta kekayaan bersama merupakan harta milik bersama yang digunakan secara bersama, hanya saja tidak boleh merugikan pihak yang beritikad baik, karena pihak yang beritikad baik juga selalu harus diuntungkan dan pihak yang beritikad buruk harus menanggung segala kerugian.

Pembatalan perkawinan dilakukan dengan mengajukan gugatan ke pengadilan dimana tempat perkawinan dilaksanakan atau di tempat suami atau istri berdomisili, asalkan masa mengajukan gugatan tidak lebih dari enam bulan. Hal ini disebutkan dalam pasal 27 UU Perkawinan: 1) Seorang suami atau istri dapat mengajukan permohonan pembatalan perkawinan apabila perkawinan dilangsungkan dibawah ancaman yang melanggar hukum; 2) Seorang suami atau istri dapat mengajukan permohonan pembatalan perkawinan apabil pada waktu berlangsungnya perkawinan terjadi salah sangka mengenai diri suami atau istri; dan 3) Apabila ancaman telah berhenti, atau yang bersalah sangka itu menyadari keadaannya,dan dlam jangka waktu enam (6) bulan setelah itu masih tetap hidup sebagai suami istri, dan tidak menggunakan hak nya untuk mengajukan permohonan pembatalan perkawinan, maka haknya gugur.

Dalam hukum islam maupun dalam Undang-undang Perkawinan membolehkan pihak yang dirugikan dalam perkawinan untuk mengajukan pembatalan perkawinan ke pengadilan agama sepanjang sesuai dengan aturan yang berlaku. Adapun proses penyelesaian parkara pembatalan perkawinan sama dengan proses perceraian. Yang mana dalam penyelesaian perkara pembatalan perkawinan tersebut tidak lepas dari adanya proses administrasi perkara di Pengadilan Agama:

1. Penggugat atau kuasanya datang kebagian pendaftaran perkara di pengadilan agama, untuk menyatakan bahwa ia ingin mengajukan gugatan. Gugatan itu diajukan dalam bentuk surat, lisan dan kemudian membayar biaya berperkara

2. Panitera pendaftarkan perkara menyampaikan gugatan kepada bagian perkara, sehingga gugatan resmi dapat diterima dan didaftarkan dalam buku registrasi perkara.

3. Wakil panitera memeriksa kelengkapan berkas dan penunjukan panitera pengganti dan juru sita.

4. Gugatan diteruskan kepada Ketua Pengadilan Agama dan diberi catatan mengenai nomor, tanggal perkara dan penetapan mejelis hakim

5. Hakim ketua atau anggota majelis hakim memeriksa kelengkapan surat gugatan dan membuat penetapan hari siding.

6. Juru sita memanggil penggugat dan tergugat dengan membawa surat panggilan sidang secara patut.

7. Sidang perkara, yang mana semua proses pemeriksaan perkara dicatat dalam berita acara persidangan.

Sedangkan perjalanan sidang diatur sebagai berikut: a) Pemanggilan para pihak yaitu pemohon dan termohon; b) Mengusahakan perdamaian antara pemohon dan termohon oleh majelis hakim; c) Apabila usaha perdamaian tidak berhasil, maka dilanjutkan dengan pembacaan surat permohonan; d) Tahap pembuktian yaitu pemeriksaan alat bukti baik berupa bukti surat maupun saksi-saksi; dan e) Pembacaan penetapan, hasilnya berdasarkan kepada hasil pemeriksaan di persidangan serta pembuktian di persidangan. 
Berdasarkan Pasal 22 Undang-undang Nomor 1 Tahun 1974, "perkawinan dapat dibatalkan apabila para pihak tidak memenuhi syarat-syarat untuk melangsungkan perkawinan". Batalnya suatu perkawinan hanya dapat diputus oleh pengadilan dan pengajuan pembatalan perkawinan hanya dapat dilakukan oleh pihak-pihak yang merasa dirugikan. Pada Pasal 23 menyebutkan yang dapat mengajukan membatalkan perkawinan adalah: 1) Para keluarga dalam garis keturunan lurus ke atas dari suami atau istri; 2) Suami atau istri; 3) Pejabat yang berwenang hanya selama perkara belum diputuskan; dan 4) Pejabat yang ditunjuk tersebut ayat (2) Pasal 16 Undang-undang ini dan setiap orang yang mempunyai kepentingan hukum secara langsung terhadap perkawinan tersebut, tetapi hanya setelah perkawinan itu diputus.

Batalnya suatu perkawinan dimulai setelah adanya putusan pengadilan yang mempunyai kekuatan hukum tetap. Dengan adanya pembatalan perkawinan, maka akan menimbulkan akibat hukum terhadap anak dan harta bersama. Akibat hukum dari pembatalan tersebut adalah putusnya perkawinan itu dan para pihak yang dibatalkan perkawinannya kembali ke status semula, karena perkawinan yang dilakukannya itu dianggap tidak sah. Di dalam Pasal 28 Undang-undang Nomor 1 Tahun 1974, putusan pembatalan perkawinan tidak berlaku surut terhadap: 1) Anak- anak yang dilahirkan dari perkawinan tersebut; 2) Suami atau istri yang bertindak dengan iktikad baik, kecuali terhadap harta bersama, bila pembatalan perkawinan didasarkan atas adanya perkawinan lain yang ada terlebih dahulu; dan 3) Orang-orang ketiga lainnya yang tidak termasuk dalam 1 dan 2 sepanjang mereka memperoleh hak-hak dengan iktikad baiksebelum keputusan tentang pembatalan mempunyai kekuatan hukum tetap.

Sedangkan menurut Kompilasi Hukum Islam Pasal 75, keputusan pembatalan perkawinan tidak berlaku surut terhadap: a) Perkawinan yang batal karena salah satu dari suami atau istri murtad; b) Anak-anak yang dilahirkan dari perkawinan tersebut; dan c) Pihak ketiga sepanjang mereka memperoleh hak-hak dengan beritikad baik, sebelum keputusan pembatalan perkawinan mempunyai kekuatan hukum yang tetap.Pasal 76 Kompilasi Hukum Islam, juga menjelaskan "batalnya suatu perkawinan tidak akan memutuskan hubungan hukum antara anak dengan orang tuanya".Dan terhadap pihak ketiga yang beritikad baik pembatalan perkawinan tidak mempunyai akibat hukum yang berlaku surut, jadi segala perbuatan perdata atau perikatan yang diperbuat oleh suami atau istri sebelum pembatalan perkawinan tetap berlaku, dan ini harus dilaksanakan oleh suami istri tersebut, sehingga pihak ketiga yang beritikad baik tidak dirugikan. Atas adanya perjanjian yang telah dilakukan, maka perjanjian yang ada harus tetap dilaksanakan sesuai dengan kesepakatan yang telah disepakati. Perlindungan hukum ini diberikan dengan mendasarkan pada Pasal 75 Kompilasi hukum Islam dan Pasal 28 Undang-undang Nomor 1 tahun 1974.

Terhadap kasus ini, pembatalan perkawinan menimbulkan akibat hukum terhadap: 1) Hubungan antara pemohon dan termohon sudah tidak terikat lagi dengan ikatan perkawinan yang sah dan hakiki; dan 2) Tidak adanya kewajiban perdata bagi pemohon maupun termohon. Hukum perdata merupakan rangkaian peraturanperaturan hukum yang mengatur hubungan hukum antara orang yang satu dengan orang yang lainnya dalam kehidupan masyarakat. Kewajiban perdata yang timbul dari suatu ikatan perkawinan adalah adanya hubungan yang timbul antara para pihak (suami istri), yang menimbulkan kewajiban antara suami dan istri, hubungan dengan keturunan dan kekuasaan orang tua serta hubungan istri dengan harta kekayaan yang mereka miliki. Namun, pada kasus ini kewajiban perdata diatas sudah dihapus karena adanya pembatalan perkawinan tersebut. 


\section{Penutup}

Proses pelaksanaan permohonan pembatalan perkawinannya di Pengadilan Agama adalah mendaftarkan permohonan perkara dan membayar biaya perkara, Panitera pendaftarkan perkara menyampaikan gugatan kepada bagian perkara, sehingga gugatan resmi dapat diterima dan didaftarkan dalam buku registrasi perkara.Wakil panitera memeriksa kelengkapan berkas dan penunjukan panitera pengganti dan juru sita.Gugatan diteruskan kepada Ketua Pengadilan Agama dan diberi catatan mengenai nomor, tanggal perkara dan penetapan mejelis hakim. Hakim ketua atau anggota majelis hakim memeriksa kelengkapan surat gugatan dan membuat penetapan hari siding.Juru sita memanggil penggugat dan tergugat dengan membawa surat panggilan sidang secara patut.Sidang perkara, yang mana semua proses pemeriksaan perkara dicatat dalam berita acara persidangan. Dalam pemeriksaan di persidangan pada sidang pertama majelis hakim berusaha mendamaikan antara pemohon dan termohon. Apabila perdamaian tidak berhasil maka persidangan dilanjutkan dengan pembacaan permohonan, selanjutnya tahap pembuktian yaitu berupa bukti surat maupun bukti saksi-saksi dan persidangan terakhir adalah pembacaan penetapan berdasarkan pemeriksaan dipersidangan dan pembuktian serta hasil musyawarah majelis hakim. Akibat hukum dari pembatalan perkawinan di Pengadilan Agama adalah Hubungan antara pemohon dan termohon sudah tidak terikat lagi dengan ikatan perkawinan yang sah dan hakiki,dan tidak adanya kewajiban perdata bagi pemohon maupun termohon.

\section{Daftar Pustaka}

Achmad Ichsan, Hukum Perkawinan Bagi Yang Beragama Islam, PT Pradyna Paramita, Jakarta, 1987.

Afandi Ali, Hukum Waris Hukum Keluarga Hukum Pembuktian, PT. Bina Aksara, Jakarta, 1984.

A Rahman Bakri dan Ahmad Sukardja, Hukum Perkawinan menurut Islam, Undangundang Perkawinan dan Hukum Perdata/BW, PT.Hidakarya Agung, 1993.

Harahap Yahya, Hukum Acara Perdata, Sinar Grafika,Jakarta,2005.

Rais Isnawati , Hukum Perkawinan dalam Islam, Departemen Agama RI, Jakarta Timur, 2006.

Syarifuddin Amir, Hukum Perkawinan Islam di Indonesia, Kencana Prenada Media Group, Jakarta, 2009

Soekanto Soerjono, Pengantar Penelitian Hukum, UI Press,Jakarta, 2007.

Sostroatmodjo Arso dan A Wasit Aulawi, Hukum Perkawinan di Indonesia, Bulan Bintang, Jakarta, 1981.

Syahrani Riduan dan Abdurrahman, Masalah-Masalah Hukum Perkawinan Di Indonesia, Penerbit Alumni, Bandung, Jakarta, 1978.

Sudarsono, Hukum Perkawinan Nasional, Rineka Cipta, Jakarta, 2005.

Zainuddin Ali, Hukum Perdata Islam di Indonesia, Sinar Grafika, 2006.

Zainuddin Ali, Metode Penelitian Hukum, Sinar Grafika, Jakarta, 2010. 